\title{
"EFEK MAGIS" BAHASA TERHADAP KESANTUNAN BERBAHASA DALAM PERISTIWA SIDANG PELANGGARAN LALU LINTAS DI PENGADILAN NEGERI SELONG
}

\section{("MAGICAL EFFECTS" OF LANGUAGE TOWARDS POLITENESS USAGE OF LANGUAGE DURING TRAFFIC VIOLATION TRIAL AT THE DISTRICT COURT OF SELONG)}

\author{
Herman Wijaya \\ STKIP Hamzanwadi Selong \\ Jalan TGKH Zainuddin Abdul Madjid No.132 Pancor 83612, Selong, NTB, Indonesia \\ Pos-el: wijaya.herman33@yahoo.com
}

Diterima: 3 Oktober 2014; Direvisi: 20 November 2014; Disetujui: 3 Desember 2014

\begin{abstract}
The power of language transfers message to the interlocutors more effectively. Exploitation of the language power positively could effect to the polite communication. Thus, the key problem of this study is to explore the form of words or speeches which contain power stimulating polite usage of language. This study is aimed at analyzing the data, forms of speech containing language power effect which is used by traffic judges during the trial of traffic violators. This study applies descriptivequalitative method to describe the data taken from the traffic judge and the violators' form of speech in the traffic violation trials. The data, in verbal form, consist of dialogues between the traffic judge and violators during the trial process. Informents of this study are the traffic judge and the violators. The data consists of forms of speech or sentences uttered by the traffic judge and the violators as well as their actons or attitudes during the trial process. The data are collected through observation techniques - in passive role - with recording technique, note taking, and audiovisual recording techniques. The data are analyzed by using interactive analysis with the following steps: data reduction, transcription of recording data, data grouping, and conclusion. Based on the data of the speech acts, it is ilustrated that the language power used by the judge to create effectsto the traffic violaters contains: questions, imperative sentences, warning, requests and prohibition. The dominant form of language power used by the judge to create communication effect towards the traffic violators is imperative form of language power. Such language power is generally the form of imperative politeness in language usage.
\end{abstract}

Keywords: power effect of language, polite usage of language

\begin{abstract}
Abstrak
Kekuatan yang terkandung di dalam bahasa mampu mengefektifkan pesan kepada mitra tutur. Pemanfaatan daya bahasa secara positif membuat efek komunikatif menjadi santun. Sehingga dengan menggali bentuk kata-kata atau ujaran-ujaran yang mengandung daya bahasa yang menimbulkan kesantunan berbahasa menjadi inti permasalahan dalam penelitian ini. Penelitian ini bertujuan untuk menganalisis data yang memiliki efek daya bahasa dari bentuk-bentuk ujaran yang digunakan hakim tilang pada sidang pelanggaran lalu lintas. Metode yang digunakan pada penelitian ini adalah deskriptif kualitatif karena data yang dideskripsikan berupa ujaran-ujaran hakim tilang dan pelaku pelanggaran pada sidang tilang. Data dari penelitian ini adalah data verbal berupa dialog antara hakim tilang dengan pelaku pelanggaran ketika proses sidang berlangsung. Sumber data berasal dari hakim tilang dan pelaku pelanggaran. Data penelitian berupa ujaran-ujaran atau kalimat yang diujarkan pada saat sidang dan tindakan atau sikap hakim dan pelaku pada saat proses sidang berlangsung.
\end{abstract}


Pengumpulan data dilakukan dengan teknik observasi berperan pasif dengan teknik sadap, catat, dan teknik rekam audiovisual. Data dianalisis dengan teknik analisis interaktif dengan langkah reduksi data, transkripsi data hasil rekaman, pengelompokan data, dan simpulan. Data dari peristiwa tutur dalam penelitian tergambar bahwa bentuk daya bahasa yang hakim gunakan untuk memberikan efek kepada pelaku pelanggaran terdiri dari daya bahasa pertanyaan, perintah, peringatan, permintaan dan larangan. Bentuk dominan daya bahasa yang hakim gunakan untuk memberikan efek komunikatif kepada pelaku pelanggaran yaitu bentuk daya bahasa perintah. Daya bahasa perintah tersebut merupakan wujud kesantunan imperatif dalam berbahasa secara santun.

Kata Kunci : efek daya bahasa, kesantunan berbahasa

\section{Pendahuluan}

Penggunaan daya bahasa dalam pengungkapan pesan dapat menimbulkan efek komunikatif yang berbeda-beda. Jika daya bahasa dimanfaatkan secara positif maka efek komunikatif dapat berjalan secara santun. Sebaliknya, jika daya bahasa dimanfaatkan secara negatif maka efek komunikatif dapat menimbulkan ketidaksantunan. Pranowo (2012:129) menyatakan daya bahasa hanya akan muncul jika pemakainya dapat menggali dan memanfaatkan dalam konteks pemakaian secara tepat. Misalnya pada kalimat "Polisi dinilai gagal dalam upaya mengatasi pelanggaran lalu lintas jika memilih jalan damai." Kata-kata gagal dan damai dalam kalimat tersebut secara leksikal memang tidak menampakkan daya apa-apa. Namun, ketika kata-kata itu dipakai dalam konteks tertentu (dituturkan oleh orang yang terkena tilang) ternyata dapat menyatakan kritik penutur kepada mitra tutur. Memunculkan daya bahasa yang sangat kuat karena kuatnya daya bahasa yang digunakan membuat kritik yang disampaikan menjadi tidak santun.

Dalam proses sidang pelanggaran lalu lintas, biasanya kesantunan berbahasa sering tidak diindahkan oleh hakim maupun terdakwa. Kalimat "Berapa pasal yang dilanggar" yang ditanyakan oleh hakim kepada seorang petani yang usianya lebih tua dari hakim tersebut, itu memberikan kesan yang kurang santun. Seharusnya hakim menggunakan kata sapaan ketika menyebut nama si terdakwa agar tuturan yang diucapkan lebih santun. Contoh lain, ketika giliran seorang mahasiswa diberikan penjelasan mengenai pelanggaran yang dilakukan, mahasiswa tersebut malah tertawa dengan posisi duduk yang asalasalan seperti posisi duduk orang yang tidak di sidang. Sikap mahasiswa seperti ini membuat hakim menjadi geram dan mengatakan "Gak usah ketawa-ketawa di sini, ini bukan tempat orang ketawa, mahasiswa kok kelakuannya kayak gini".

Gambaran peristiwa dari uraian di atas menimbulkan ketidaksantunan berbahasa. Ketidaksantunan berbahasa yang dilakukan oleh hakim disebabkan karena: Pertama, nada bicara hakim yang keras menggambarkan suasana hatinya yang marah. Kedua, hakim tidak bisa mengendalikan diri sehingga mengeluarkan emosinya. Ketiga, hakim mengkritik secara langsung lawan tuturnya. Chaer (2010: 6970) menyatakan bahwa penyebab ketidaksantunan itu antara lain adalah: (a) mengkritik secara langsung dengan menggunakan kata-kata kasar; (b) dorongan emosi penutur; (c) sengaja menuduh lawan tutur; (d) protektif terhadap pendapat sendiri; dan (e) sengaja memojokkan lawan tutur. Sedangkan ketidaksantunan yang diperlihatkan oleh mahasiswa tersebut bisa ditilik dari unsur-unsur nonverbal yang dilakukannya. Unsur-unsur nonverbal yang dimaksud adalah kinesika dan proksemika. Ekspresi wajah santai disertai tertawa yang dilakukan mahasiswa tersebut, itu termasuk 
dalam unsur kinesika. Sedangkan tata cara atau posisi duduk yang semaunya ketika disidang, itu termasuk unsur proksimik.

Peristiwa yang terjadi pada sidang tilang tidak hanya gambaran ketidaksantunan berbahasa. Namun, gambaran kesantunan berbahasa pun lazim terjadi. Misalnya, hakim menggunakan kata sapaan "Bapak" ketika yang menjadi terdakwa tilang adalah seorang pegawai. Di sisi lain, seorang pelajar memperlihatkan kesantunannya ketika menjadi terdakwa tilang. Ia duduk dengan posisi yang tepat kemudian menjawab pertanyaan dari hakim dengan sopan dan mendengarkan semua penjelasan hakim. Begitu pula, ketika hakim berkata: "Lain kali, kalau berkendaraan jangan lupa simnya di bawa ya Pak", ini menunjukkan perhatian hakim terhadap pegawai ini agar tidak lupa membawa sim ketika berkendara. Kalimat tersebut memunculkan daya bahasa peringatan yang sangat kuat kepada mitra tutur. Karena dipakai dalam konteks yang tepat serta tergambar tuturan kearifan penutur sehingga daya bahasa peringatan yang disampaikan menjadi santun. Dalam gambaran proses sidang pelanggaran lalu lintas tersebut, terlihat adanya ketimpangan dan perbedaan tata tutur hakim terhadap terdakwa yang seorang petani dengan terdakwa yang seorang pegawai. Kemudian, perbedaan tata laku yang diterima hakim dari terdakwa tilang yang seorang mahasiswa dengan terdakwa tilang yang seorang pelajar.

\section{Landasan Teori}

\subsection{Efek Daya Bahasa}

\subsubsection{Menggali Daya Bahasa Melalui Aspek Kebahasaan}

Setiap orang dapat berbahasa, tetapi tidak setiap orang dapat memanfaatkan daya bahasa untuk mengefektifkan komunikasi. Setiap bunyi, kata, struktur sebenarnya mengandung daya bahasa. Daya bahasa dapat digali melalui berbagai aspek bahasa seperti bunyi, bentuk kata, kalimat, pilihan kata maupun struktur. Sudaryanto (dalam Pranowo, 2012:129--130) menyatakan bahwa pada tataran bunyi, bunyi /i/ memiliki makna yang menggambarkan keadaan yang dipersepsi sebagai sesuatu yang kecil pada suatu benda, seperti kata "kerikil", "cukil", "pentil". "kutil", dan sebagainya. Dalam kutipan puisi yang berbunyi "Setelah dahi dan pipi kalian ibu ciumi", bunyi /i/ pada kata (dahi, pipi, ciumi) memunculkan daya bahasa yang dapat dipersepsi sebagai perasaan seorang ibu yang "sedih" untuk melepas kepergian anaknya.

Bunyi /o/ dapat memunculkan daya bahasa yang berimajinasi dengan "kuat", seperti kata "gerombol", "benjol", "dongkol", dan sebagainya. Jadi, pada tataran bunyi, bunyi bahasa dapat menunjukkan daya bahasa yang berbedabeda. Kata yang mengandung bunyi /i/ memunculkan daya bahasa yang berimajinasi dengan makna "kecil" dan dapat pula mengimajinasikan makna "kesedihan". Sedangkan kata yang mengandung bunyi /o/ memunculkan daya bahasa yang berimajinasi dengan makna "kuat dan besar."

Menurut Pranowo (2012:135--136) daya bahasa dapat pula digali melalui sinonim kata. Kata satu dengan kata lain sinonimnya memiliki daya bahasa yang berbeda-beda, seperti kata mati dan meninggal memiliki daya bahasa yang bersifat netral. Sedangkan kata mampus dan gugur memiliki daya bahasa yang lebih spesifik. Kata mampus memiliki daya bahasa negatif yang di dalamnya mengandung rasa dendam dan penuh kepuasan karena orang lain yang dibencinya tidak dapat berbuat apa-apa lagi. Kata gugur memiliki daya bahasa yang hormat terhadap seseorang karena kematiannya terjadi untuk melakukan perjuangan sehingga perlu mendapat penghargaan/penghormatan. Sedangkan kata senang memiliki daya 
bahasa yang berbeda dengan kata gembira dan riang. Kata gembira memiliki daya bahasa yang mengandung rasa puas terhadap suatu keadaan yang diungkapkan dengan keceriaan wajah sambil senyum-senyum. Kata riang mengandung daya bahasa rasa puas terhadap suatu keadaan yang diungkapkan dengan tersenyum disertai gerakan tubuh seperti menari, menyanyi/bersenandung. Daya bahasa dapat pula digali pada tataran struktur kalimat. Misalnya pada contoh berikut seperti (a) Kamu bisa menjadi apa pun yang kamu mau jika kamu bersedia bekerja keras (b) Jika kamu bersedia bekerja keras maka kamu bisa menjadi apa pun yang kamu mau.

Daya bahasa pada kalimat di atas terletak pada penempatan klausa pada awal kalimat. Kalimat (a) dengan menempatkan klausa "kamu bisa menjadi apa pun yang kamu mau" memunculkan daya bahasa yang lebih memberikan motivasi dengan menempatkan kompensasi di awal kalimat. Sebaliknya, kalimat (b) dengan menempatkan klausa "jika kamu bersedia bekerja keras" kurang memotivasi karena memberikan perhatian pada hal yang perlu dilakukan dengan menempatkannya di awal kalimat. "Daya bahasa pada tataran struktur memiliki kadar pesan yang berbeda antara struktur kalimat satu dengan struktur kalimat yang lain" (Pranowo, 2012:136).

Berdasarkan uraian di atas, dapat disimpulkan bahwa mengkaji daya bahasa melalui aspek kebahasaan dapat melalui aspek bahasa seperti pada tataran bunyi, bentuk kata, pilihan kata, maupun struktur kalimat. Pada tataran bunyi biasanya terdapat dalam persajakan dan asonansi bunyi yang pada kata-kata tertentu dapat menimbulkan efek makna yang lebih kuat daripada kalau kata-kata dipakai tanpa memperhatikan persajakan.

\subsection{Menggali Daya Bahasa Melalui Aspek Pragmatik}

Daya bahasa dapat digali melalui aspek pragmatik. Dari aspek pragmatik, daya bahasa dapat digali melalui maksimmaksim kesantunan berbahasa. Leech (2011:205-207) menyatakan bahwa maksimmaksim yang dapat menjelaskan hubungan antara makna dengan daya dalam percakapan dapat menggunakan beberapa maksim kesantunan, yaitu: (a) maksim kearifan (memaksimalkan keuntungan bagi mitra tutur); (b) maksim kedermawanan (mamaksimalkan kerugian pada diri sendiri); (c) maksim pujian (memaksimalkan pujian kepada mitra tutur); (d) maksim kerendahan hati (minimalkan pujian untuk diri sendiri); (e) maksim kesepakatan (memaksimalkan kesepakatan dengan mitra tutur); (f) maksim simpati (memaksimalkan ungkapan simpati kepada mitra tutur).

Penggunaan maksim-maksim di atas dapat meminimalkan pengungkapan maksud yang dapat melukai hati mitra tutur. Namun, akibatnya tuturan banyak disampaikan dalam bentuk tidak langsung. Levinson (dalam Pranowo, 2012:140) menyatakan bahwa untuk mengoptimalkan daya bahasa, terutama daya bahasa yang cenderung tidak santun, penutur biasanya menggunakan implikatur. Nadar (2009:60) "Implikatur berarti sesuatu yang diimplikasikan dalam suatu percakapan." Tidak berbeda jauh dengan pendapat tersebut, Leech (dalam Nadar, 2011:60) menyebutkan bahwa menginterpretasikan suatu tuturan sebenarnya merupakan usaha-usaha untuk menduga, yang dalam bahasa lain yang lebih terhormat merupakan suatu pembentukan hipotesa. Dengan kata lain, "Implikatur merupakan tebakan tidak langsung dari suatu penggunaan bahasa, atau suatu tindak tutur, mulai dari yang paling sederhana sampai yang rumit" (Pangaribuan, 2008:133). 
Berdasarkan pendapat dari berbagai pakar di atas, dapat disimpulkan bahwa menelaah daya bahasa melalui aspek pragmatik dapat dikaji melalui maksimmaksim kesantunan berbahasa yang disertai dengan penggunaan implikatur percakapan agar tuturan dapat diinterpretasikan.

\subsection{Kesantunan Berbahasa}

\subsubsection{Teori Kesantunan}

Lakoff (dalam Chaer, 2010:46) mengatakan kalau tuturan ingin terdengar santun di telinga lawan tutur, ada tiga kaidah kesantunan yang harus dipatuhi, yaitu: (a) formalitas (formality); (b) ketidaktegasan (hesitancy); (c) persamaan atau kesekawanan (equality or cameraderie). Jadi, sebuah tuturan dikatakan santun apabila ia tidak terdengar memaksa, memberi pilihan kepada lawan tutur, dan lawan tutur merasa tenang. Berkaitan dengan kesopanan atau kesantunan dalam praktik bertutur sapa, Rahardi (2006:94) menyatakan bahwa semakin akrab dan dekat relasi antara bahasa dan konteks tutur, antara bahasa dengan pemakainya maka akan semakin tinggi kadar kesantunannya.

Senada dengan hal tersebut, Gunarwan (dalam Chaer, 2010:47--48) menyatakan bahwa ada tiga hal yang perlu diperhatikan dalam kesantunan, yaitu: Pertama, kesantunan itu adalah properti atau bagian dari tuturan. Kedua, pendapat pendengarlah yang menentukan apakah kesantunan itu terdapat pada sebuah tuturan. Ketiga, kesantunan itu dikaitkan dengan hak dan kewajiban peserta pertuturan. Hak yang dimaksudkan di sini adalah sesuatu yang menjadi milik penutur atau lawan tutur. Sedangkan kewajiban yang dimaksud di sini adalah keharusan yang harus dilakukan oleh peserta pertuturan. Di antara hak-hak penutur dalam suatu proses pertuturan adalah hak untuk bertanya dan salah satu yang menjadi kewajiban peserta pertuturan adalah kewajiban untuk menjawab.
Leech (2011:206--217) mengajukan teori kesantunan berdasarkan prinsip kesantunan yang dijabarkan menjadi maksim-maksim berikut ini: (a) maksim kebijaksanaan, maksim penerimaan, maksim kemurahan hati dan maksim kerendahan hati adalah maksim yang berhubungan dengan keuntungan atau kerugian diri sendiri dan orang lain; (b) maksim kecocokan dan maksim kesimpatian adalah maksim yang berhubungan dengan penilaian buruk atau baik penutur terhadap dirinya sendiri atau orang lain; (c) maksim kebijaksanaan dan maksim kemurahan hati adalah maksim yang berpusat pada orang lain; (d) maksim penerimaan dan kerendahan hati adalah maksim yang berpusat pada diri sendiri. Pakar lain, Rahardi (2009:26) kesantunan sebuah tuturan dapat dilihat dari banyak sedikitnya tuturan memberikan pilihan kepada mitra tutur. Bilamana sebuah tuturan tidak menyediakan pilihan bagi mitra tutur maka itu memiliki kadar kesantunan yang rendah. Sebaliknya, jika sebuah tuturan memiliki banyak pilihan yang digunakan sebagai alternatif bagi mitra tutur maka itu dapat dikatakan memiliki kadar kesantuan tingkat tinggi.

\subsubsection{Skala Kesantunan}

Lakoff (dalam Chaer, 2010:63--64) menyatakan ada tiga skala kesantunan, yaitu: (a) skala formalitas menyatakan bahwa agar peserta pertuturan merasa nyaman dalam kegiatan bertutur maka tuturan yang digunakan tidak boleh bernada memaksa dan tidak boleh terkesan angkuh; (b) skala ketidaktegasan menunjukkan agar penutur dan lawan tutur dapat saling merasa nyaman dalam bertutur, maka pilihanpilihan dalam bertutur harus diberikan oleh kedua belah pihak; (c) skala kesekawanan menunjukkan untuk selalu bersikap ramah dan selalu mempertahankan persahabatan antara penutur dan lawan tutur. Senada dengan pendapat tersebut, Brown dan 
Levinson (dalam Chaer, 2010:64--65) menyodorkan tiga skala penentu tinggi rendahnya peringkat kesantunan sebuah tuturan, yaitu: (a) skala peringkat sosial antara penutur dan petutur banyak ditentukan oleh parameter perbedaan umur, jenis kelamin, dan latar belakang sosiokultural; (b) skala peringkat status sosial antara penutur dan petutur didasarkan pada kedudukan asimetrik antara penutur dan lawan tutur; (c) skala peringkat tindak tutur didasarkan atas kedudukan relatif tindak tutur yang satu dengan lainnya.

Berbeda dengan Brown dan Levinson yang menyodorkan tiga skala, (Leech, 2011:194--196) menyodorkan lima buah skala pengukur kesantunan berbahasa, yaitu: (a) skala kerugian dan keuntungan merujuk pada besar kecilnya biaya dan keuntungan yang disebabkan oleh sebuah tindak tutur pada sebuah tuturan; (b) skala pilihan mengacu pada banyak atau sedikitnya pilihan yang disampaikan penutur kepada lawan tutur di dalam kegiatan bertutur; (c) skala ketidaklangsungan merujuk kepada peringkat langsung atau tidak langsungnya maksud sebuah tuturan; (d) skala keotoritasan merujuk kepada hubungan status sosial antara penutur dan lawan tutur yang terlibat dalam suatu pertuturan; (e) skala jarak sosial merujuk kepada peringkat hubungan sosial antara penutur dan lawan tutur yang terlibat dalam suatu pertuturan.

\subsubsection{Indikator Kesantunan}

Hymes (dalam Pranowo, 2012:100-101) menyatakan bahwa agar komunikasi dapat mencerminkan kesantunan berbahasa, maka ada beberapa komponen tutur yang harus diperhatikan, yaitu: (a) setting and scene mengacu pada tempat dan waktu terjadinya komunikasi; (b) paricipants mengacu pada orang yang terlibat dalam komunikasi; (c) ends mengacu pada orang yang terlibat dalam berkomunikasi; (d) act sequence mengacu pada bentuk dan pesan yang ingin disampaikan; (e) key mengacu pada pelaksanaan percakapan; (f) norms mengacu pada norma perilaku partisipan; (g) genres mengacu pada ragam bahasa yang digunakan.

Grice (dalam Pranowo, 2012:102) menyatakan bahwa santun tidaknya pemakaian bahasa dapat ditandai dengan beberapa hal, sebagai berikut: (a) ketika berbicara mampu menjaga martabat mitra tutur; (b) ketika berkomunikasi tidak mengatakan hal-hal yang kurang baik mengenai mitra tutur; (c) tidak mengungkapkan rasa senang atas kemalangan mitra tutur; (d) tidak menyatakan ketidaksetujuan dengan mitra tutur; (e) tidak memuji atau membanggakan diri sendiri. Sejalan dengan pendapat tersebut, Pranowo (2012:103--104) menyatakan bahwa agar komunikasi dapat terasa santun, tuturan ditandai dengan halhal berikut: (a) memperhatikan suasana mitra tutur; (b) mempertemukan perasaan penutur dengan mitra tutur sehingga isi komunikasi sama-sama dikehendaki; (c) menjaga agar tuturan dapat diterima oleh mitra tutur; (d) menjaga agar dalam tuturan terlihat ketidakmampuan penutur dihadapan lawan tutur; (e) menjaga agar tuturan memperlihatkan posisi lawan tutur selalu berada pada posisi yang lebih tinggi; (f) menjaga agar tuturan selalu terlihat bahwa apa yang dikatakan kepada lawan tutur juga dirasakan oleh penutur.

Berdasarkan ulasan-ulasan pendapat dari para pakar di atas, dapat disimpulkan bahwa indikator kesantunan adalah penanda yang dapat dijadikan sebagai penentu apakah pemakaian bahasa yang digunakan si penutur dapat dikatakan santun atau tidak.

\subsection{Pelanggaran Lalu Lintas}

\subsubsection{Pengertian Pelanggaran Lalu Lintas}

Pelanggaran lalu lintas tertentu atau yang sering disebut dengan tilang 
merupakan kasus dalam ruang lingkup hukum pidana yang diatur dalam UU Nomor 14 Tahun 1992. Hukum pidana mengatur perbuatan-perbuatan yang dilarang oleh undang-undang dan berakibat diterapkannya hukuman bagi siapa yang melakukannya dan memenuhi unsur-unsur perbuatan yang disebutkan dalam undang-undang pidana. Pelanggaran lalu lintas adalah suatu pelanggaran terhadap ketentuan perundangundangan lalu lintas dan angkutan jalan yang berlaku dan dilakukan oleh seseorang baik dengan menggunakan kendaraan maupun berjalan kaki sehingga mudah untuk dibuktikan (Kamtibmas, 2013:6).

Dari uraian tersebut, dapat disimpulkan bahwa pelanggaran lalu lintas adalah suatu bentuk pelanggaran terhadap ketentuan yang berlaku dalam peraturan lalu lintas yang dilakukan oleh seseorang baik menggunakan kendaraan bermotor maupun tidak. Pelanggaran lalu lintas atau yang biasa disebut tilang termasuk dalam ruang lingkup kasus hukum pidana.

\subsubsection{Teknik Pelaksanaan Penindakan Pelanggaran Lalu Lintas}

Ada beberapa langkah dalam teknik pelaksanaan penindakan pelanggaran lalu lintas, yakni: (a) teknik patroli stationer: berhenti disuatu tempat pada waktu antara 10 sampai dengan 15 menit lalu berpindah lagi; (b) teknik patroli bergerak dengan cara membuntuti: patroli membuntuti sampai dengan posisi siap untuk melaksanakan penghentian dan penindakan pelanggaran; (c) teknik mengintai kendaraan dengan bergerak; (d) teknik menghentikan kendaraan (Kamtibmas, 2013:9--10).

Berdasarkan uraian tersebut dapat disimpulkan bahwa teknik pelaksanaan dalam penindakan pelanggaran lalu lintas terdiri dari empat teknik, yakni: teknik patroli strationer, teknik patroli bergerak, teknik mengintai, dan teknik menghentikan kendaraan.

\subsubsection{Bentuk-bentuk Pelanggaran Lalu Lintas}

Bentuk-bentuk pelanggaran lalu lintas diantaranya sebagai berikut: (a) menggunakan jalan dengan cara yang dapat merintangi, membahayakan ketertiban atau keamanan lalu lintas atau yang mungkin menimbulkan kerusakan pada jalan; (b) mengemudikan kendaraan bermotor yang tidak dapat memperlihatkan surat izin mengemudi (SIM), STNK, Surat Tanda Uji Kendaraan (STUK) yang sah atau tanda bukti lainnya sesuai peraturan yang berlaku atau dapat memperlihatkan tetapi masa berlakunya sudah kadaluwarsa; (c) membiarkan atau memperkenakan kendaraan bermotor dikemudikan oleh orang lain yang tidak memiliki SIM; (d) tidak memenuhi ketentuan peraturan perundangundangan lalu lintas jalan tentang penomoran, penerangan, peralatan, perlengkapan, pemuatan kendaraan dan syarat penggandengan dengan kendaraan lain; (e) membiarkan kendaraan bermotor yang ada di jalan tanpa dilengkapi plat tanda nomor kendaraan yang sah, sesuai dengan surat tanda nomor kendaraan yang bersangkutan; (f) pelanggaran terhadap perintah yang diberikan oleh petugas pengatur lalu lintas jalan, rambu-rambu atau tanda yang ada di permukaan jalan; (g) pelanggaran terhadap ketentuan-ketentuan tentang ukuran dan muatan yang diizinkan, cara menaikkan dan menurunkan penumpang dan atau cara memuat dan membongkar barang; (h) pelanggaran terhadap izin trayek, jenis kendaraan yang diperbolehkan beroperasi di jalan yang ditentukan (Kamtibmas, 2013:13--14).

Berdasarkan uraian tersebut, dapat disimpulkan bahwa bentuk-bentuk pelangaran lalu lintas yakni terdiri dari: menggunakan jalan semaunya, tidak memiliki perlengkapan mengemudi, membiarkan orang yang tidak memiliki SIM mengendarai motor, tidak mengindahkan 
peraturan lalu lintas, melanggar ramburambu lalu lintas, melanggar ketentuan angkutan, dan pelanggaran terhadap izin trayek.

\subsubsection{Dampak Pelanggaran Lalu Lintas}

Permasalahan yang terjadi pada kondisi lalu lintas di Indonesia telah menimbulkan berbagai masalah khususnya menyangkut permasalahan lalu lintas. Permasalahan tersebut, seperti: (a) tingginya angka kecelakaan lalu lintas baik pada persimpangan lampu lalu lintas maupun pada jalan raya; (b) keselamatan para pengendara dan para pejalan kaki menjadi terancam; (c) kemacetan lalu lintas akibat dari masyarakat yang enggan untuk berjalan kaki atau memanfaatkan sepeda ontel; (d) kebiasaan melanggar peraturan lalu lintas yang biasa kemudian menjadi budaya melanggar peraturan (Kamtibmas, 2013:16).

\section{Metodologi Penelitian}

Penelitian ini merupakan jenis penelitian deskriptif kualitatif. Metode yang digunakan dalam penelitian ini adalah metode deskriptif. Menurut Moleong (2011:11) Metode deskriptif yaitu, data yang dikumpulkan berupa kata-kata dan bukan dalam bentuk angka sehingga laporan penelitian akan berisi kutipan-kutipan data untuk memberikan gambaran-gambaran penyajian dari laporan tersebut. Lokasi penelitian dilakukan di Pengadilan Negeri Selong yang beralamat di jalan Prof. Soepomo No. 1 Selong dengan pertimbangan bahwa pengadilan ini memiliki ruang khusus untuk sidang pelanggaran lalu lintas. Sumber data dalam penelitian ini terdiri dari pelaku pelanggaran lalu lintas, hakim tilang beserta komponen hukum.

Teknik yang digunakan untuk mengumpulkan data dalam penelitian ini yaitu teknik observasi berperan pasif. Peneliti hanya mencatat, merekam dan menggunakan teknik sadap. Validasi data penelitian ini menggunakan trianggulasi. Data yang sudah terkumpul kemudian peneliti gali dari beberapa sumber data yang berbeda agar lebih mantap kebenarannya. Teknik analisis data penelitian ini adalah teknik analisis interaktif. Teknik ini menggambarkan aktivitas yang dilakukan dengan cara berinteraksi antara komponen proses analisis dan proses pengumpulan data yang berbentuk siklus (Sutopo, 2002:95). Model analisis interaktif ini meliputi pengumpulan data, reduksi data, penyajian data, penarikan simpulan dan verifikasi.

\section{Pembahasan}

Bentuk daya bahasa yang dominan menimbulkan kesantunan berbahasa hakim dapat dideskripsikan sebagai berikut.

\subsection{Daya Bahasa Pertanyaan}

Daya bahasa pertanyaan merupakan kekuatan yang terkandung di dalam bahasa yang digunakan untuk memberi pertanyaan kepada mitra tutur dengan tujuan untuk mendapatkan respon.

Tabel 1. Contoh Daya Bahasa Pertanyaan

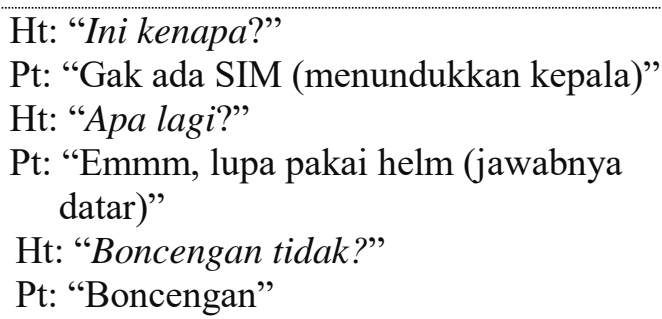

\section{Ht: "Apa gunanya helm?"}

Pt: "(ditanya seperti itu, Pt grogi dan ia mengusap kedua tangannya di celana jeansnya sambil menjawab) "Untuk melindungi badan"

Ht: "Dari apa?"

Pt: "Emm... tabrakan (jawabnya dengan suara agak kecil)" 
Dari beberapa pertanyaan yang dilontarkan hakim di atas, pertanyaan yang memberikan efek kepada pelaku tilang terdapat pada pertanyaan "Apa gunanya helm?" Pertanyaan tersebut merupakan bentuk tuturan dengan fungsi untuk menanyakan pendapat atau buah pikiran yang dilontarkan hakim kepada terdakwa tilang. Pertanyaan "Apa gunanya helm?" jika ditanyakan oleh orang lain selain hakim tilang maka pertanyaan itu mungkin tidak memunculkan daya bahasa apa pun. Sebaliknya, ketika pertanyaan tersebut diucapkan oleh hakim tilang pada saat sidang dan ditujukan kepada terdakwa tilang maka itu akan memunculkan daya bahasa yang sangat kuat. Ini dapat dilihat dari reaksi atau tindakan yang tergambar dari pelaku tilang yang ditanya. Ketika hakim bertanya seperti itu, pelaku tilang kelihatan pucat dan grogi serta salah tingkah sampai-sampai ia mengusap-usapkan tangannya yang geregetan di celana jeans yang dikenakannya. Respon tersebut menampak- kan bahwa pertanyaan hakim itu memberikan efek kepada pelaku tilang.

Dalam hal ini, pertanyaan yang dilontarkan hakim tersebut dinilai memiliki efek daya bahasa yang membuat tuturan hakim menjadi santun. Kesantunan tuturan hakim yang menanyakan "Apa gunanya helm?" dapat kita buktikan dari skala pengukur kesantunan dari Brown dan Levinson, yakni skala peringkat status sosial yang didasarkan pada kedudukan asimetrik antara penutur dengan lawan tutur. Di dalam ruang sidang tilang, seorang hakim memiliki peringkat kekuasaan lebih tinggi dibandingkan dengan terdakwa tilang. Karena hakim memiliki kekuasaan yang lebih tinggi maka tidak ada salahnya jika hakim ingin bertanya mengenai apa kegunaan helm. Di samping itu juga, pertanyaan hakim sudah sesuai dengan konteksnya. Pertanyaan hakim tersebut dinilai memiliki daya bahasa yang dapat menimbulkan kesantunan berbahasa hakim.

Tabel 2. Contoh Daya Bahasa Pertanyaan

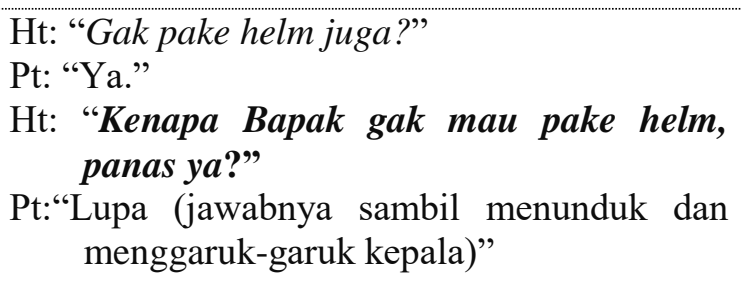

Pt:"Lupa (jawabnya sambil menunduk dan menggaruk-garuk kepala)"

Dari dialog di atas, pertanyaan hakim yang memberikan efek kepada pelaku tilang terdapat pada pertanyaan "Kenapa Bapak gak mau pake helm, panas ya?" Pertanyaan tersebut merupakan bentuk tuturan dengan fungsi menanyakan meminta alasan yang dilontarkan hakim kepada terdakwa tilang. Pertanyaan "Kenapa Bapak gak mau pake helm, panas ya? " juga memiliki daya bahasa yang kuat terhadap terdakwa tilang karena yang menanyakan hal tersebut adalah
Ht:"Bagaimana gak masuk angin kalau gak mau pake helm"

Pt:"(diam dan memperhatikan hakim)"

Ht: "Tiga puluh satu ribu!"

Pt: "(langsung berdiri)

seorang hakim tilang pada saat proses sidang. Beda halnya jika pertanyaan tersebut diucapkan pada waktu dan tempat serta suasana yang berbeda. Oleh karena itu, pertanyaan tersebut mungkin tidak menimbulkan daya bahasa apa pun. Pengaruh dari daya bahasa pertanyaan "Kenapa Bapak gak mau pake helm, panas $y a$ ? " ini dapat kita lihat dari tata laku orang yang ditanya atau respon dari terdakwa tilang. Ketika hakim menanyakan hal itu, terdakwa tilang menjawab dengan suara 
yang agak kecil sambil menunduk dan menggaruk-garuk kepala. Ini menandakan bahwa terdakwa tilang merasa sedikit malu dengan pertanyaan yang diajukan hakim tersebut.

Dalam hal ini, pertanyaan yang diujarkan hakim tersebut dinilai memiliki efek daya bahasa yang membuat tuturan hakim menjadi santun. Kesantunan tuturan hakim yang menanyakan "Kenapa Bapak gak mau pake helm, panas ya?" dapat kita buktikan dari penggunaan kata sapaan yang sesuai dengan identitas penutur dan lawan tutur. Hakim menggunakan kata sapaan "Bapak" kepada terdakwa tilang karena umur yang didakwa lebih tua dari hakim. Selain kata "Bapak", hakim juga menggunakan kata "panas ya?" di akhir kalimat untuk memberikan nuansa gurauan. Nada bercanda atau bergurau yang dilakukan hakim tersebut merupakan salah satu aspek penentu kesantunan dalam bahasa verbal lisan. Sehingga terlihat kearifan penutur ketika bertanya kepada terdakwa tilang. Karena itu, pertanyaan hakim tersebut dinilai mengandung daya bahasa yang bisa berpengaruh terhadap kesantunan bahasa yang hakim gunakan.

\subsection{Daya Bahasa Perintah}

Daya bahasa perintah merupakan kekuatan yang terkandung di dalam bahasa yang digunakan untuk menyuruh orang lain melakukan sesuatu yang diinginkan oleh orang yang memerintah.

Tabel 3. Contoh Daya Bahasa Perintah

\section{Ht: "Buka topinya Pak!'}

Pt: "(langsung melepaskan topi yang dikenakannya dan memperbaiki cara duduknya)"

Ht: "Ini boncengan ya, siapa yang bawa ini?"

Pt: "Anak saya. Dia makeq cuma pada waktu sekolah saja karna gak ada yang nganterin"

Dari dialog di atas, kalimat yang mengandung daya bahasa perintah terdapat pada kalimat "Buka topinya, Pak!". Daya bahasa perintah yang dilontarkan hakim kepada terdakwa tilang pada saat sidang, itu merupakan bentuk tuturan dengan fungsi memerintah. Perintah "Buka topinya, Pak!" yang diucapkan hakim kepada terdakwa tilang, itu berpengaruh sekali kepada terdakwa tilang karena yang menyuruh untuk melepaskan topi tersebut adalah hakim tilang pada saat sidang. Pengaruh dari daya bahasa perintah "Buka topinya, Pak!" terlihat dari respon yang ditunjukkan terdakwa tilang. Ketika hakim menyuruh terdakwa untuk melepaskan topi yang
Ht: "Umur berapa anaknya?"

Pt: "15 tahun"

Ht: "15 tahun belum boleh bawa SIM, nanti kalau ada apa-apa dengan anaknya belum bisa tanggung jawab ya karna umurnya masih belum ini"

Pt: "Geh..geh"

dikenakan, ia langsung melepaskannya tanpa pikir panjang dan ia juga memperbaiki cara duduknya dengan sopan. Berkaitan dengan ini, kalimat perintah yang diucapkan hakim pada saat proses sidang berlangsung dinilai memiliki efek daya bahasa terhadap kesantunan ucapan hakim. Kesantunan itu terlihat dari penggunaan kata sapaan "bapak" yang disingkat menjadi "pak" yang hakim gunakan ketika menyuruh terdakwa untuk membuka topinya. Hakim menyuruh terdakwa membuka topi untuk menghormati persidangan karena memang tidak dibolehkan memakai topi di ruang sidang. Sehingga, daya bahasa perintah tersebut dirasakan sopan. 
Tabel 4. Contoh Daya Bahasa Perintah

\begin{tabular}{l|l|} 
Ht: "Banyak sekali pelanggarannya. Adek yang & Ht: "Pasang spionnya dua ya! Jangan \\
bawa motornya?" & takut hilang kecantikan kalau pakai \\
helm dan spion. Justru orang yang \\
Pt: "Iya" \\
$\begin{array}{l}\text { Ht: "Pake helm gak?" } \\
\text { Pt: "Gak (menggeleng)" }\end{array}$ \\
$\begin{array}{l}\text { Ht: "Terus motornya ada kaca spionnya? itu orang banyak yang } \\
\text { Pt:"Ndak ada (katanya sambil tersenyum)" }\end{array}$ \\
teguran)" \\
Pt:"(mendengarkan dan mengangguk)"
\end{tabular}

Tuturan hakim dari dialog di atas yang mengandung daya bahasa perintah terdapat pada tuturan "Pasang spionnya dua ya!". Tuturan yang dilontarkan hakim tersebut merupakan bentuk tuturan dengan fungsi memerintah. Perintah "Pasang spionnya dua ya!" yang dilontarkan hakim kepada terdakwa tilang maksudnya menyuruh terdakwa agar memasang spion dengan lengkap agar tidak ditilang lagi. Daya bahasa perintah tersebut memiliki efek komunikatif kepada terdakwa tilang. Efek komunikatif dari bahasa perintah tersebut yakni terdakwa bisa menerima dan menyadari kesalahannya yang ditunjukkan dengan sikap memperhatikan hakim ketika diperintah untuk memasang spion serta mengiyakan apa yang diperintah oleh hakim tanpa menyanggah sedikitpun. Sehingga, kalimat perintah "Pasang spionnya dua ya!" yang diucapkan hakim pada saat proses sidang berlangsung dinilai memiliki efek daya bahasa terhadap kesantunan ucapan hakim. Kesantunan itu terlihat dari aspek nada bicara hakim yang tidak terlalu keras dan disertai dengan senyuman.

\subsection{Daya Bahasa Peringatan}

Daya bahasa peringatan merupakan kekuatan yang terkandung di dalam bahasa yang disampaikan dengan maksud memberikan peringatan kepada mitra tutur.

Tabel 5. Contoh Daya Bahasa Peringatan Ht: "Sudah berapa lama bawa motor?"
Pt: "Memang itu kan hari jumat tetapi itu kan
hari libur waktu saya balik dari Alas
(sambil menggerakkan tangannya yang
kanan). Oh sudah lama.

Tuturan hakim yang mengandung daya bahasa peringatan dari dialog di atas terdapat pada tuturan "tetap saja namanya SIM itu surat izin mengemudi dan itu penting buat Bapak". Tuturan hakim tersebut merupakan bentuk tuturan dengan fungsi untuk memberikan peringatan atau pengarahan. Peringatan "tetap saja namanya SIM itu surat izin mengemudi dan itu
Ht: "Ya sudah lama. Walaupun hari libur ya, tetap saja namanya SIM itu surat izin mengemudi dan itu penting buat Bapak. Jadi bagaimanapun keadaannya harus tetap dibawa ya?"

Pt: "Ya..ya (mengangguk-angguk dan mendengarkan penjelasan hakim dengan serius)"

penting buat Bapak" jika dinyatakan oleh orang lain selain hakim tilang maka peringatan itu mungkin tidak memunculkan daya bahasa apa pun. Sebaliknya, ketika peringatan tersebut diucapkan oleh hakim tilang pada saat sidang dan ditujukan kepada terdakwa tilang maka itu akan memunculkan daya bahasa yang sangat kuat. Ini dapat dilihat dari reaksi yang tergambar dari 
pelaku tilang yang ditanya. Ketika hakim memperingatkan seperti itu, pelaku tilang tidak bergeming sedikitpun dan kelihatan memperhatikan dengan serius serta mengangguk-angguk. Respon yang seperti itu menandakan bahwa peringatan yang diberikan hakim diterima dengan sangat baik oleh terdakwa dan memberikan pengertian kepada terdakwa tilang akan pentingnya kelengkapan kendaraan. Peringatan yang dituturkan hakim tersebut dinilai memiliki efek daya bahasa yang membuat tuturan hakim menjadi santun. Kesantunan tuturan hakim tergambar dari penggunaan kata sapaan serta terlihat dari perhatian hakim kepada terdakwa tilang agar terdakwa tilang tidak mengulangi lagi kesalahannya. Sehingga, kalimat peringatan yang diujarkan berpengaruh terhadap kesantunan berbahasa hakim.

Tabel 6. Contoh Daya Bahasa Peringatan

Ht: "Banyak sekali ini. Gak pake helm juga Pt: "Iya" ya? Gak lengkap dong motornya? (tanya hakim)"

Pt: "Lengkap buk (jawabnya sambil senyumsenyum)"

Ht: "jangan bohong di sini. Di sini sudah ada pasalnya (kata hakim menegaskan)"

Tuturan hakim yang mengandung daya bahasa peringatan dari dialog di atas, terdapat pada tuturan "Kalau bohong, saya tambahkan nanti dendanya". Tuturan tersebut merupakan bentuk tuturan dengan fungsi memberikan peringatan. Peringatan "Kalau bohong, saya tambahkan nanti dendanya" yang diucapkan hakim kepada terdakwa tilang, itu berpengaruh sekali kepada terdakwa tilang karena yang memberikan peringatan untuk tidak berbohong adalah hakim tilang pada saat proses sidang. Pengaruh dari daya bahasa peringatan tersebut terlihat dari sikap yang ditunjukkan terdakwa tilang. Ketika hakim memperingatkan terdakwa untuk jangan bermain-main atau berbohong mengenai pasal yang dilanggar, si terdakwa langsung takut dan segera memperbaiki cara duduknya dengan sopan. Berkaitan dengan
Ht: "Kalau bohong, saya tambahkan nanti dendanya"

Pt: "(kelihatan takut dan memperbaiki posisi duduk)"

$\mathrm{Ht}$ : "Gak lengkapa ya?"

Pt: "Iya (mengangguk)"

ini, kalimat peringatan yang diucapkan hakim pada saat proses sidang berlangsung dinilai memiliki efek daya bahasa terhadap kesantunan ucapan hakim. Kesantunan itu terlihat dari sikap hakim yang tidak kesal dengan kebohongan terdakwa dan nada bicara hakim ketika memberi peringatan pun tidak keras. Sehingga, daya bahasa peringatan tersebut terdengar santun dan masih dirasakan sopan.

\subsection{Daya Bahasa Permintaan}

Daya bahasa permintaan merupakan kekuatan yang terkandung di dalam bahasa yang digunakan untuk meminta orang lain untuk melakukan sesuatu. Kalimat permintaan disebut juga dengan kalimat permohonan. Kata-kata yang biasa digunakan dalam kalimat permintaan antara lain, yakni kata tolong dan mohon.

Tabel 7. Contoh Daya Bahasa Permintaan

\begin{tabular}{|l|l} 
Ht: "Ini gak pakai helm, terus? & $\begin{array}{l}\text { Pt: "Berdua, yang dibelakang gak pakai helm } \\
\text { Pt: "Cuman itu" }\end{array}$ \\
$\begin{array}{l}\text { Ht: "Cuman itu? (tanya hakim mengetes). } \\
\text { mengangat tangan kanannya dan }\end{array}$ \\
$\begin{array}{l}\text { Mohon minta kejujuran semuanya" } \\
\text { Ht: "Emm.. tapi kalau lagi sekali, dua-duanya harus }\end{array}$
\end{tabular}


Pt: "Iya memang cuman itu (memperbaiki tempat duduk)"

Ht: "Side sendiri ini?" pakai helm ya. SIM nanti cari SIM ya?"

Pt: "Geh, tapi belum bisa buat SIM"

H: "Gak pake helm juga?"

Pt: :Geh..."
Tuturan hakim yang mengandung daya bahasa permintaan dari dialog di atas terdapat pada kalimat "Mohon minta kejujuran semuanya". Tuturan tersebut merupakan bentuk permintaan halus dari hakim agar si terdakwa tidak memberikan kesaksian palsu mengenai pasal-pasal apa saja yang dilanggar. Penggunaan daya bahasa permintaan tersebut membuat terdakwa memberikan respon yang baik terhadap permintaan hakim. Sehingga, kalimat permintaan hakim dinilai memiliki pengaruh terhadap lawan tuturnya. Setelah mendengar kalimat permintaan hakim tersebut, terdakwa tilang memperbaiki tempat duduknya dan sikapnya. Terdakwa merasa tuturan hakim tersebut santun didengar. Selain dari kosakata yang digunakan, kesantunan hakim juga tergambar dari sikapnya. Gunarwan (dalam Chaer, 2010:47) menyatakan bahwa pendapat pendengarlah yang menentukan apakah kesantunan itu terdapat pada sebuah tuturan. Jadi, kalimat permintaan yang diucapkan hakim tersebut merupakan bentuk daya bahasa yang bisa menimbulkan kesantunan berbahasa hakim.

Tabel 8. Contoh Daya Bahasa Permintaan
Ht: "Kenapa gak pake helm, Pak?"
Pt: "Lupa, soalnya terburu-buru waktu itu mau ke tempat orang ninggal (katanya menjelaskan)"

Ht: "Walaupun terburu-buru harus pake ya pak ya karna terburu-buru kurang baik apalagi ini gak pake. Tolong diingetin ininya ya (memegeng kepala), sayang kepala"

Pt: "Ya...(mengangguk)"
Tuturan hakim yang mengandung daya bahasa permintaan dari dialog di atas terdapat pada kalimat "tolong diingetin ininya ya (memegeng kepala), sayang kepala". Tuturan hakim tersebut merupakan bentuk tuturan dengan fungsi meminta. Permintaan "Tolong diingetin ininya ya (memegeng kepala), sayang kepala" yang diucapkan hakim kepada terdakwa tilang, itu maksudnya mengingatkan terdakwa untuk memakai helm setiap berkendaraan agar tidak terjadi apa-apa pada kepala terdakwa seandainya terjadi kecelakaan. Daya bahasa permintaan tersebut memiliki efek komunikatif kepada terdakwa tilang. Efek komunikatif dari bahasa permintaan tersebut yakni terdakwa bisa menyadari betapa pentingnya memakai helm dalam berkendaraan. Terdakwa juga mengiyakan permintaan hakim dengan penuh khidmat. Sehingga, kalimat permintaan "Tolong diingetin ininya ya (memegeng kepala), sayang kepala" yang diucapkan hakim pada saat proses sidang berlangsung dinilai memiliki efek daya bahasa terhadap kesantunan ucapan hakim. Kesantunan itu juga terlihat dari respon terdakwa yang menerima permintaan hakim untuk dirinya agar selalu ingat memakai helm.

\subsection{Daya Bahasa Larangan}

Daya bahasa larangan merupakan kekuatan yang terkandung di dalam bahasa yang disampaikan dengan maksud melarang orang untuk melakukan sesuatu. Biasanya digunakan kata-kata dilarang dan jangan. 
Tabel 9. Contoh Daya Bahasa Larangan

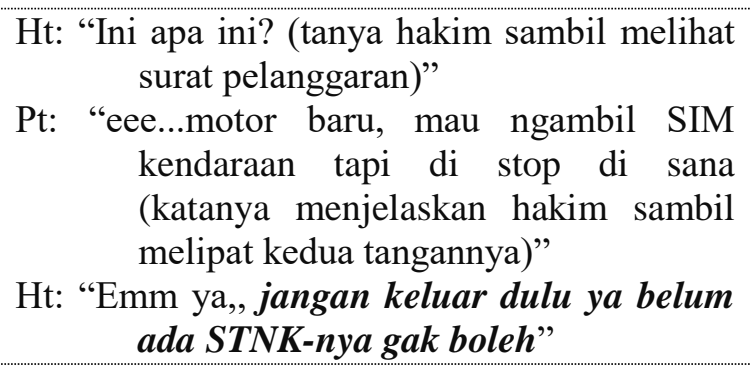

Ht: "Ini apa ini? (tanya hakim sambil melihat surat pelanggaran)"

Pt: "eee...motor baru, mau ngambil SIM kendaraan tapi di stop di sana (katanya menjelaskan hakim sambil melipat kedua tangannya)"

Ht: "Emm ya, jangan keluar dulu ya belum ada STNK-nya gak boleh"

Tuturan yang mengandung daya bahasa larangan dari dialog di atas terdapat pada kalimat "jangan keluar dulu ya belum ada STNK-nya" dan kalimat "iya ambil tapi jangan pakai motornya yang itu, kan itu belum boleh". Tuturan tersebut merupakan bentuk tuturan dengan fungsi melarang lawan tutur untuk sesuatu hal. Larangan yang diucapkan hakim kepada terdakwa tilang, itu berpengaruh sekali kepada terdakwa tilang. Pengaruh dari daya bahasa larangan di atas terlihat dari sikap yang ditunjukkan terdakwa tilang. Semula terdakwa ngotot dan berusaha untuk membela diri tapi ketika hakim dengan tegas mengucapkan daya bahasa larangan tersebut terdakwa malah tidak berani membela diri lagi. Terdakwa memang merasa bersalah dan sadar akan kesalahannya. Itulah efek yang ditimbulkan dari daya bahasa larangan hakim.
Pt: "Kita mau mengambilnya tapi buk. Dealer telp, ambil STNK-nya dia bilang (berusaha membela diri di depan hakim)"

Ht: "Iya ambil tapi jangan pakai motornya yang itu, kan itu belum boleh ya"

Pt: "Iya buk (sambil mengangguk)"
Berkaitan dengan hal tersebut, kalimat
larangan yang diucapkan hakim pada saat proses sidang berlangsung memiliki bentuk daya bahasa yang bisa menimbulkan kesantunan berbahasa hakim. Kesantunan itu bisa dibuktikan juga dari skala pengukur kesantunan Brown dan Levinson, yakni skala peringkat status sosial yang didasarkan pada kedudukan asimetrik antara penutur dengan lawan tutur. Di dalam ruang sidang tilang, seorang hakim memiliki peringkat kekuasaan lebih tinggi dibandingkan dengan terdakwa tilang. Karena hakim memiliki kekuasaan yang lebih tinggi maka tidak ada salahnya jika hakim menggunakan kata-kata larangan untuk memberi peringatan kepada terdakwa. Kalimat larangan hakim tersebut juga sudah sesuai dengan konteksnya. Sehingga, larangan hakim tersebut dinilai memiliki daya bahasa yang dapat menimbulkan kesantunan berbahasa hakim.

Tabel 10. Contoh Daya Bahasa Larangan

Ht: "Banyak sekali ini. Gak pake helm juga
ya? Gak lengkap dong motornya? (tanya
hakim)"
Pt: "Lengkap buk (jawabnya sambil senyum-
senyum)"
Ht: "jangan bohong di sini. Di sini sudah ada
pasalnya (kata hakim menegaskan)"

Tuturan hakim yang mengandung daya bahasa larangan dari dialog di atas terdapat pada kalimat "Jangan bohong di sini. Di sini sudah ada pasalnya”. Hakim melarang untuk memberikan kesaksian palsu
Pt: "Iya (menunduk)"
Ht: "Kalau bohong, saya tambahkan nanti
dendanya"
Pt: "(kelihatan takut dan memperbaiki posisi
duduk)"
Ht: "Gak lengkapa ya?"
Pt: "Iya (mengangguk)" atau kebohongan mengenai hal-hal apa saja yang dilanggar terdakwa ketika ditilang. Daya bahasa larangan tersebut sangat berpengaruh kepada terdakwa tilang. Terdakwa yang semula santai dan senyum- 
senyum menjawab pertanyaan-pertanyaan dari hakim, tiba-tiba berubah menjadi tegang dan bersikap sopan. Cara duduknya yang semula asal-asalan berubah menjadi rapi dan tegap. Begitu juga ketika hakim menggunakan daya bahasa larangan tersebut, terdakwa menunduk dan menerima kata-kata larangan hakim dengan mengangguk. Raut wajahnya juga tampak menyesal karena telah berbohong. Namun, walaupun hakim mengucapkan kalimat tersebut dengan tegas tidak lantas tuturan hakim tersebut dirasakan kasar. Akan tetapi kearifan tuturan hakim dapat dirasakan santun karena hakim mengucapkannya pada konteks yang tepat sehingga membuat daya bahasa larangan tersebut menjadi santun.

\section{Penutup}

Berdasarkan hasil analisis dan pembahasan hasil analisis data yang dipaparkan maka dapat disimpulkan bahwa bentuk daya bahasa yang dapat menimbulkan kesantunan berbahasa hakim pada sidang pelanggaran lalu lintas di Pengadilan Negeri Selong meliputi daya bahasa pertanyaan yang digunakan untuk menanyakan bentuk tuturan dengan fungsi meminta alasan yang dilontarkan hakim kepada terdakwa tilang. Pengaruh daya bahasa peringatan terlihat dari sikap yang ditunjukkan terdakwa tilang. Ketika hakim memperingatkan terdakwa untuk jangan bermain-main atau berbohong mengenai pasal yang dilanggar, si terdakwa langsung takut dan segera memperbaiki cara duduknya dengan sopan. Daya bahasa perintah memiliki efek komunikatif kepada terdakwa tilang. Efek komunikatif dari bahasa perintah tersebut yakni terdakwa bisa menerima dan menyadari kesalahannya yang ditunjukkan dengan sikap memperhatikan hakim ketika diperintah untuk memasang spion serta mengiyakan apa yang diperintah oleh hakim tanpa menyanggah sedikitpun. Daya bahasa permintaan memiliki efek komunikatif kepada terdakwa tilang. Efek komunikatif dari bahasa permintaan tersebut yakni terdakwa bisa menyadari betapa pentingnya memakai helm dalam berkendaraan. Terdakwa juga mengiyakan permintaan hakim dengan penuh khidmat. Pengaruh dari daya bahasa larangan di atas terlihat dari sikap yang ditunjukkan terdakwa tilang. Semula terdakwa ngotot dan berusaha untuk membela diri tapi ketika hakim dengan tegas mengucapkan daya bahasa larangan tersebut terdakwa malah tidak berani membela diri lagi. Karena terdakwa memang merasa bersalah dan sadar akan kesalahannya. Itulah efek yang ditimbulkan dari daya bahasa larangan hakim. Bentuk daya bahasa yang paling banyak digunakan hakim dalam sidang pelanggaran lalu lintas adalah daya bahasa perintah. Daya bahasa perintah adalah kekuatan yang terkandung di dalam bahasa yang digunakan untuk menyuruh orang lain melakukan sesuatu yang diinginkan oleh orang yang memerintah. Penggunaan bentuk daya bahasa perintah merupakan wujud kesantunan imperatif hakim pada peristiwa sidang pelanggaran lalu lintas.

\section{Daftar Pustaka}

Chaer, Abdul. (2010). Kesantunan Berbahasa. Jakarta: Rineka Cipta.

Harkamtibmas. (2013). "Pengetahuan tentang Pelanggaran Lalu Lintas dan Proses Penyelesaiannya (Modul)". Selong: Korlantas.

(2013). "Etika dan Tata Cara Berlalu Lintas (Modul)". Selong: Korlantas. (2013). "Pengantar UU No 2 Tahun 2009 tentang Lalu Lintas dan 
Mabasan, Vol. 8 No.2, Juli-Desember 2014 : 125-140

Angkutan Jalan (Modul)". Selong: Korlantas.

(2013). "Pengetahuan tentang SIM (Modul)". Selong: Korlantas.

(2013). "Pengetahuan tentang STNK (Modul)". Selong: Korlantas.

(2013). "Pengetahuan tentang BPKB (Modul)". Selong: Korlantas.

Leech, Geoffrey. (2011). Prinsip-prinsip Pragmatik. Jakarta: Universitas Indonesia.

Moleong, L.J. (2013). Metodologi Penelitian Kualitatif (Edisi Revisi). Bandung: Remaja Rosdakarya.
Nadar, F.X. (2009). Pragmatik dan Penelitian Pragmatik. Yogyakarta: Graha Ilmu.

Pranowo. (2012). Berbahasa secara Santun. Yogyakarta: Pustaka Pelajar.

Rahardi, Kunjana. (2006). Bahasa Kaya Bahasa Berwibawa. Yogyakarta: ANDI.

Sutopo. (2002). Metodologi Penelitian Kualitatif Dasar Teori dan Penerapannya dalam Penelitian. Surakarta: University Sebelas Maret Press. 